\title{
Szabadgyök-felszabadulás vizsgálata femtoszekundumos lézerrel asszisztált capsulotomiát követően
}

\author{
Tóth Gábor dr. ${ }^{1}$ - Sándor Gábor László dr. ${ }^{1}$ \\ Kleiner Dénes ${ }^{2}$ - Szentmáry Nóra dr. ${ }^{1,3}$ - Kiss Huba J. dr. ${ }^{1}$ \\ Blázovics Anna dr. ${ }^{2}$ - Nagy Zoltán Zsolt dr. ${ }^{1}$ \\ Semmelweis Egyetem, 'Általános Orvostudományi Kar, Szemészeti Klinika, \\ ${ }^{2}$ Gyógyszerésztudományi Kar, Farmakognóziai Intézet, Budapest \\ ${ }^{3}$ Saarvidéki Egyetem, Szemészeti Klinika, Homburg/Saar, Németország
}

\begin{abstract}
Bevezetés: A femtoszekundum lézer alkalmazása forradalmi, innovatív kezelési eljárás a szürkehályog-sebészetben. Célkitüzés: Tanulmányunk célja a femtoszekundum lézeres capsulotomia során az elülső csarnokban képződô szabad gyök mennyiségének meghatározása sertésszemben. Módszer: Hetven friss sertésszemet vontunk be a vizsgálatba, amelyeket post mortem 2 órán belül $4{ }^{\circ} \mathrm{C}$ hőmérsékleten szállítottunk, a kezelést pedig 7 órán belül végeztük el. Harmincöt szemet vizsgáltunk a kontroll- és a femtoszekundum lézeres capsulotomia csoportban is. Luminoldependens kemilumineszcens módszer segítségével vizsgáltuk a csarnokvíz szabadgyök-fogó kapacitását, mint a szabadgyök-termelődés indikátorát. Az emittált fotonok mennyiségét relatív fényegység százalékban fejeztük ki. Eredmények: A relatív fényegység százalék alacsonyabb volt a kontrollcsoportban (medián $1 \%$, interkvartilis tartomány 0,4-3\%), mint a femtoszekundum lézeres capsulotomia csoportban (medián 4,4\%, interkvartilis tartomány 1,5-21\%) $(\mathrm{p}=0,01)$. Következtetések: A femtoszekundum lézeres capsulotomia gyengíti a csarnokvíz antioxidáns védelmét, amely a femtoszekundum lézeres capsulotomia során felszabaduló szabad gyökök hatására utal. Orv. Hetil., 2016, 157(47), 1880-1883.
\end{abstract}

Kulcsszavak: kemilumineszcencia, kemilumineszcens femtoszekundum lézerrel asszisztált szürkehályog-mútét, szabad gyök, szabadgyök-fogó kapacitás

\section{Evaluation of free radical quantity in the anterior chamber following femtosecond laser-assisted capsulotomy}

\begin{abstract}
Introduction: Femtosecond laser is a revolutionary, innovative treatment method used in cataract surgery. Aim: To evaluate free radical quantity in the anterior chamber of the eye, during femtosecond laser assisted capsulotomy, in a porcine eye model. Method: Seventy fresh porcine eyes were collected within 2 hours post mortem, were transported at $4{ }^{\circ} \mathrm{C}$ and treated within 7 hours. Thirty-five eyes were used as control and 35 as femtosecond laser assisted capsulotomy group. A simple luminol-dependent chemiluminescence method was used to measure the total scavenger capacity in the aqueous humour, as an indicator of free radical production. The emitted photons were expressed in relative light unit $\%$. Results: The relative light unit $\%$ was lower in the control group (median $1 \%$, interquartile range $[0.4-3 \%]$ ) than in the femtosecond laser assisted capsulotomy group (median 4.4\%, interquartile range [1.5\%-21\%]) $(\mathrm{p}=0.01)$. Conclusions: Femtosecond laser assisted capsulotomy decreases the antioxidant defense of the anterior chamber, which refers to a significant free radical production during femtosecond laser assisted capsulotomy.
\end{abstract}

Keywords: chemiluminescence, femtosecond laser-assisted cataract surgery, free radical, total scavenger capacity

Tóth, G., Sándor, G. L., Kleiner, D., Szentmáry, N., Kiss, H., Blázovics, A., Nagy, Z. Zs. [Evaluation of free radical quantity in the anterior chamber following femtosecond laser-assisted capsulotomy]. Orv. Hetil., 2016, 157(47), $1880-1883$.

(Beérkezett: 2016. augusztus 18.; elfogadva: 2016. szeptember 15.) 


\section{Rövidítések}

$\mathrm{FL}=$ femtoszekundum lézer; FLACS = femtoszekundum lézerrel asszisztált szürkehályog-mútét; FLC $=$ femtoszekundum lézeres capsulotomia; IQR = interkvartilis tartomány; $\mathrm{KO}=$ kontroll; RLU = relatív fényegység; SFK = szabadgyök-fogó kapacitás

A femtoszekundum lézer (FL) segítségével végzett capsulotomia (FLC) 2009 óta használatos eljárás a szürkehályog-sebészetben [1]. Az utóbbi években számos tanulmány jelent meg az FLC előnyeiről a hagyományos, phacoemulsificatiós technikával szemben. Az FLC a cataractasebészetben ma már széles körben alkalmazott, közkedvelt eljárás.

Az FLC segítségével pontosabb és egyszerüen reprodukálható capsulotomiás nyílás [2, 3] készítése lehetséges, csökken a mútét során felhasznált ultrahang-energia [4], illetve a posztoperatív szaruhártya- $[5,6]$ és maculaoedema [7] kialakulásának valószínűsége. Ennek ellenére az FLC intraocularis hatásai még többnyire ismeretlenek.

Habár az FLC növeli a sebészi biztonságot és javítja a szürkehályog-mütét posztoperatív eredményeit [8,9], a szaruhártya endothelialis sejtkárosodása még mindig komoly mütéti szövődménynek számít, hiszen az endothelialis sejtek jelentős károsodása a szaruhártya dekompenzálódásához vezethet [10]. A phacoemulsificatiós eljárás következtében kialakuló posztoperatív endothelsejt-károsodásban szerepe van a phacoemulsificatiós időnek és energiának, a mechanikai és hókárosodásnak, illetve a szabadgyök-képződésnek is.

A szabadgyök-képződés az egyik legfontosabb, a szürkehályog-műtét során kialakuló endothelsejt-károsodáshoz vezető folyamat [11-15].

Elöször Shimmura és mtsai mutatták ki in vitro körülmények között, hogy phacoemulsificatio közben szabad gyökök szabadulnak fel [14]. Holst és mtsai ugyanezt nyúlkísérletek során is igazolták [16]. Baumgart és mtsai pedig kimutatták, hogy az FLC használata reaktívoxigén-gyökök felszabadulásához vezet a sejtsebészeti eljárások során [17].

Tanulmányunk célja, hogy sertésszemeken végzett kísérlet segítségével megvizsgáljuk a femtoszekundum lézeres capsulotomia (FLC) során az elülső csarnokban képződő szabad gyökök mennyiségét.

\section{Módszer}

Hetven enukleált, friss sertésszemet vontunk be a kísérletbe. A szemeket egy helyi vágóhídról szállítottuk $4{ }^{\circ} \mathrm{C}$ hőmérsékleten post mortem 2 órán belül, az FLC-kezeléseket pedig 7 órán belül végeztük el. Az enukleált sertésszemeket véletlenszerüen válogattuk be a kontroll$(\mathrm{KO} ; \mathrm{n}=35$ darab) és az FLC- $(\mathrm{n}=35$ darab $)$ csoportokba.
A KO-csoportban a paracentesist követően a csarnokvizet egy 26 G injekciós tú és egy inzulinos fecskendő segítségével szívtuk le.

Az FLC-csoportban a capsulotomiát FL segítségével végeztük el (LenSx Laser, Alcon Laboratories Inc., Fort Worth, TX, Amerikai Egyesült Államok). A capsulotomiás nyílás átmérője $5 \mathrm{~mm}$, a pulzusenergia $5 \mu \mathrm{J}$, a bemetszési mélység pedig $600 \mu \mathrm{m}$ volt. Az FL-kezelést követően a csarnokvizet szintén a fent leírt módon szívtuk le. Ezt követően a begyưjiött mintákat a vizsgálataink elvégzéséig $-80^{\circ} \mathrm{C}$ hőmérsékleten tároltuk.

\section{A szabadgyök-fogó kapacitás (SFK) mérése}

Az SFK mérését a Blázovics és mtsai [18] által kidolgozott, Berthold-Lumat 9501 luminométerre (Berthold Technologies, Bad Wildbad, Németország) adaptált indukált kemilumineszcencia-módszer segítségével végeztük. A műszer spektrális tartománya 390 és 620 nm között van.

A reakciós elegy $0,30 \mathrm{~mL} \mathrm{H}_{2} \mathrm{O}_{2}$-ot $\left(30 \%\right.$-os $\mathrm{H}_{2} \mathrm{O}_{2} 10^{-4}$ hígítása), 0,30 $\mathrm{mL}$ mikroperoxidáz katalizátort ( $1 \mathrm{mM}$ ) és $0,05 \mathrm{~mL}$ luminolt $(\mathrm{pH} 9,8 ; 0,07 \mathrm{mM}$ ) (minden esetben Sigma-Aldrich, St. Louis, MO, Amerikai Egyesült Államok) tartalmazott. A csarnokvízmintákat a $\mathrm{H}_{2} \mathrm{O}_{2} / \bullet \mathrm{OH}$-mikroperoxidáz-luminol rendszerhez adtuk, majd a mérés előtt 10 másodpercen keresztül vortexkeverővel kevertük.

Az emittált fotonok számát 30 másodpercen keresztül mértük és végül relatív fényegység százalékban (RLU\%) fejeztük ki: RLU\% = $100 \times\left(\mathrm{RLU}_{\text {minta }} / \mathrm{RLU}_{\text {vak }}\right)$.

A $\mathrm{H}_{2} \mathrm{O}_{2} / \bullet \mathrm{OH}$-mikroperoxidáz-luminol rendszer lúgos $\mathrm{pH}$-n fényt bocsát ki, mert a Fenton-típusú reakcióban képződött • OH-gyök gerjeszti a luminolt. A kemilumineszcencia gátlódni fog, ha a reakcióelegyhez bármilyen szöveti mintát adunk. A vizsgált SFL annál kisebb, minél kisebb a mintánk szabadgyök-fogó képessége és minél nagyobb a mintában lévő szabad gyökök mennyisége. Minél kisebb a jel RLU\%-ban kifejezett értéke, annál nagyobb a vizsgált minta $S F K-j a$, ami pedig fordítottan korrelál a mintában lévő szabad gyökök mennyiségével.

\section{Statisztikai elemzések}

A statisztikai számításokat Statistica 8.0 szoftverrel (StatSoft Inc., Tulsa, OK) végeztük. Az adatokat medián értékben és interkvartilis tartományban (IQR) adtuk meg.

A csoportok közötti különbségeket Mann-Whitneyféle U-teszttel elemeztük. A p $\leq 0,05$ értéket tekintettük statisztikailag szignifikánsnak.

\section{Eredmények}

Az FLC- és a KO-csoportoknál mért RLU\%-értékek az 1. ábrán láthatók. A medián RLU\% 4,4\% volt az FLC- és 


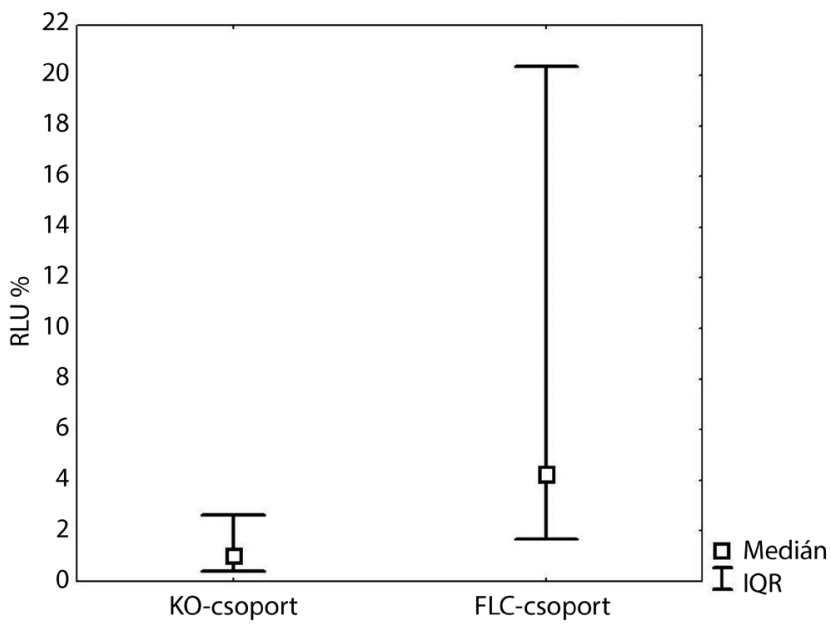

1. ábra

Relatív fényegység százalék (RLU\%) a femtoszekundum lézere capsulotomia (FLC-) csoportban és a kontroll- (KO-) csoportban $(\mathrm{p}=0,01)$

$\mathrm{IQR}$ = interkvartilis tartomány

1\% a KO-csoport esetében. A két csoport közötti különbség statisztikailag szignifikáns volt $(\mathrm{p}<0,01)$. Az eredmények tartománya $(0,5-79,2 \%)$ és az IQR (IQR: 1,5\%-21\%) az FLC-csoportban sokkal szélesebb volt, mint a KO-csoportban (0,1-13\%; IQR: 0,4\%-3\%).

\section{Megbeszélés}

Tudomásunk szerint ez az első olyan tanulmány, amely az FLC szabadgyök-felszabadulásra való hatását vizsgálja a csarnokvízben. Sertésszemeken végzett kísérleteink során kisebb SFG-t találtunk az FLC-csoportban, mint a KO-csoportban, ami a lézer múködése miatt a csarnokvízben felszabaduló szabad gyökök hatásával magyarázható. A csarnokvíz antioxidáns védelmének változása, SFK-jának csökkenése az oxidatív stressz indikátora: a megnövekedett szabadgyök-termelődés hatására csökken a csarnokvíz SFK-ja [19].

A csarnokvíz a benne lévő antioxidánsok segítségével gátolhatja vagy csökkentheti a szemben a szabad gyökök hatására kialakuló oxidatív sérülést. A csarnokvíznek számos exogén ( $\beta$-karotin, aszkorbinsav, E-vitamin) és endogén (szuperoxid dizmutáz, kataláz, glutation-peroxidáz) antioxidáns hatású védelmi mechanizmusa van, amely kapcsolatba lép a különböző szabad gyökökkel, és egy stabilabb kémiai vegyület kialakulásának elősegítésével korlátozza a szabad gyökök által okozott károsodást a szemben $[20,21]$.

Eredményeink azt mutatják, hogy a csarnokvíz antioxidáns védelmi rendszere csökkentette az FLC hatására felszabadult szabad gyökök mennyiségét, a felszabaduló prooxidánsok pedig jelentősen csökkentették a csarnokvíz SFK-ját.

A legtöbb, a szabad gyökök mennyiségi meghatározására alkalmas teszt speciális kémiai reakciókat vagy kü- lönböző féle antioxidánsok koncentrációját (enzimek, vitaminok, funkcionális csoportok) vizsgálja, amelyek nem képviselik a minta teljes antioxidáns rendszerét. A hidroxil szabad gyökök rendkívül reaktív vegyületek, féléletidejük mikroszekundumos nagyságú, ezért mérésük in vivo környezetben nagyon bonyolult [22]. Emiatt egy minta teljes antioxidáns védelmének a meghatározásához többféle mérési módszer is szükséges [23]. A különböző módszerekkel végzett tesztek eredményei azonban gyakran ellentmondásosak, mivel az antioxidánsok detektálása a biológiai rendszerekben igen bonyolult. Ezzel szemben az oxidatív stressz és az SFK csökkenése jól mérhető, például a kemilumineszcens módszerrel [18].

Az FL hatására a lézer és a szövet találkozási pontjában fotodiszrupció megy végbe, ami plazmaképződéshez és -táguláshoz (szabad elektronok és ionizált molekulák felhője), illetve szöveti károsodáshoz vezet. A szövetek elpárolgása szén-dioxid- és vízgőztartalmú kavitációs buborékok képződésével jár együtt, amelyek szétszóródnak az elülső csarnokban és érintkezésbe kerülnek a szomszédos anatómiai struktúrákkal [24-26]. A kavitációs buborékok minden valószínűség szerint szabad gyököket tartalmaznak. Murano és munkatársainak vizsgálatai szerint az oxidatív stressz apoptózist indukálhat a cornealis endothelsejtekben. A szabad gyökök károsítják a plazmamembránok, a mitokondriumok, az endoplazmatikus reticulum és a sejtmagok membránrendszerét, illetve közvetlenül hatnak a DNS-transzkripcióra, amely hatások következtében sejtoedema és -necrosis alakulhat ki [11].

A szürkehályog-műtét során kialakuló cornealis endothelsejt-károsodás komoly szövődmények forrása lehet a mütétet követően. A cataractasebészeknek tudatában kell lenniük a lehetséges komplikációknak és vigyázniuk kell az endothelsejtek épségére a mütét során, különösen akkor, ha a preoperatív sejtsưrûség alacsony.

A femtoszekundum lézerrel asszisztált szürkehályogmưtét (FLACS) során felszabadult szabad gyökök feltehetőleg nem jelentenek jelentős megterhelést a szemnek, mivel a mútéti technika egyéb elönyei (csökkent phacoemulsificatiós energia [27] és -idő [1,28], kisebb biomechanikai károsodás [29]) valószínúleg kompenzálják a lehetséges káros hatásokat. A nemzetközi szakirodalomban fellelhető tanulmányok szerint a FLACS és a konvencionális, phacoemulsificatiós műtétek között nincs jelentős különbség az intraoperatív endothelsejt-károsodás tekintetében $[5,6,27,29]$.

FLACS előtt a magas rizikójú páciensek (cornea guttata, Fuchs szaruhártya-disztrófia) antioxidánstartalmú szemcseppekkel (például: aszkorbinsav) való elókezelése elősegíthetné a mütét során felszabaduló szabad gyökök neutralizálását és biztosíthatná az endothelsejtek védelmét a további károsodástól. 


\section{Következtetések}

Az FLC hatására gyengül a csarnokvíz antioxidáns védelmi rendszere, amit az FLC során felszabaduló szabad gyökök hatásával magyarázhatunk. Mindemellett további tanulmányok szükségesek a FLACS és a hagyományos phacoemulsificatiós szürkehályog-mütét során felszabaduló szabad gyökök mennyiségének és hatásának megállapítására és összehasonlítására.

Anyagi támogatás A közlemény megírása, illetve a kapcsolódó kutatómunka anyagi támogatásban nem részesült.

Szerzői munkamegosztás: N. Z. Zs., B. A.: A vizsgálat tervezése, lefolytatása, a kézirat megszövegezése. S. G. L., K. D., Sz. N., K. H.: A kézirat megszövegezése. T. G.: A vizsgálat lefolytatása, a kézirat megszövegezése. A cikk végleges változatát valamennyi szerző elolvasta és jóváhagyta.

Érdekeltségek: N. Z. Zs.: Az Alcon-LenSx konzultánsa. A többi szerzőnek nincsenek érdekeltségei.

\section{Irodalom}

[1] Nagy, Z., Takács, A., Filkorn, T., et al.: Initial clinical evaluation of an intraocular femtosecond laser in cataract surgery. J. Refract. Surg., 2009, 25(12), 1053-1060.

[2] Nagy, Z. Z., Kránitz, K., Takács, A. I., et al.: Comparison of intraocular lens decentration parameters after femtosecond and manual capsulotomies. J. Refract. Surg., 2011, 27(8), 564-569.

[3] Kránitz, K., Takács, A., Mibáltz, K., et al.: Femtosecond laser capsulotomy and manual continuous curvilinear capsulorrhexis parameters and their effects on intraocular lens centration. J. Refract. Surg., 2011, 27(8), 558-563.

[4] Conrad-Hengerer, I., Hengerer. F. H., Schultz, T., et al.: Effect of femtosecond laser fragmentation on effective phacoemulsification time in cataract surgery. J. Refract. Surg., 2012, 28(12), 879-883.

[5] Takács, A. I., Kovács, I., Miháltz, K., et al.: Central corneal volume and endothelial cell count following femtosecond laser-assisted refractive cataract surgery compared to conventional phacoemulsification. J. Refract. Surg., 2012, 28(6), 387-391.

[6] Conrad-Hengerer, I., Al Juburi, M., Schultz, T., et al.: Corneal endothelial cell loss and corneal thickness in conventional compared with femtosecond laser-assisted cataract surgery: threemonth follow-up. J. Cataract Refract. Surg., 2013, 39(9), 13071313.

[7] Ecsedy, M., Mibáltz, K., Kovács, I., et al.: Effect of femtosecond laser cataract surgery on the macula. J. Cataract Refract. Surg., 2011, 27(10), 717-722.

[8] Nagy, Z. Z.: New technology update: femtosecond laser in cataract surgery. Clin. Ophthalmol., 2014, 8, 1157-1167.

[9] Nagy, Z. Z., Mastropasqua, L., Knorz, M. C.: The use of femtosecond lasers in cataract surgery: review of the published results with the LenSx system. J. Refract. Surg., 2014, 30(11), 730740 .

[10] Takahashi, H., Sakamoto, A., Takabashi, R., et al.: Free radicals in phacoemulsification and aspiration procedures. Arch. Ophthal mol., 2002, 120(10), 1348-1352.
[11] Murano, N., Ishizaki, M., Sato, S., et al.: Corneal endothelial cell damage by free radicals associated with ultrasound oscillation. Arch. Ophthalmol., 2008, 126(6), 816-821.

[12] Hull, D. S., Green, K., Thomas, L., et al.: Hydrogen peroxidemediated corneal endothelial damage. Induction by oxygen free radical. Invest. Ophthalmol. Vis. Sci., 1984, 25(11), 1246-1253.

[13] Hull, D. S.: Oxygen free radicals and corneal endothelium. Trans. Am. Ophthalmol. Soc., 1990, 88, 463-511.

[14] Shimmura, S., Tsubota, K., Oguchi, Ү., et al.: Oxiradical-dependent photoemission induced by a phacoemulsification probe. Invest. Ophthalmol. Vis. Sci., 1992, 33(10), 2904-2907.

[15] Rubowitz, A., Assia, E. I., Rosner, M., et al.: Antioxidant protection against corneal damage by free radicals during phacoemulsification. Invest. Ophthalmol. Vis. Sci., 2003, 44(5), 1866-1870.

[16] Holst, A., Rolfsen, W., Svensson, B., et al.: Formation of free radicals during phacoemulsification. Curr. Eye Res., 1993, 12(4), 359-365.

[17] Baumgart, J., Kuetemeyer, K., Bintig, W., et al.: Repetition rate dependency of reactive oxygen species formation during femtosecond laser-based cell surgery. J. Biomed. Opt., 2009, 14(5), 054040 .

[18] Blázovics, A., Kovács, Á., Lugasi, A., et al.: Antioxidant defence in erythrocytes and plasma of patients with active and quiescent Crohn's disease and ulcerative colitis: A chemiluminescent study. Clin. Chem., 1999, 45(6), 895-896.

[19] Nucci, C., Di Pierro, D., Varesi, C., et al.: Increased malondialdehyde concentration and reduced total antioxidant capacity in aqueous humor and blood samples from patients with glaucoma. Mol. Vis., 2013, 19, 1841-1846.

[20] Cameron, M. D., Foyer, J. F., Aust, S. D.: Identification of free radicals produced during phacoemulsification. J. Catataract Refract. Surg., 2001, 27(3), 463-470.

[21] Goyal, A., Srivastava, A., Sihota, R., et al.: Evaluation of oxidative stress markers in aqueous humor of primary open angle glaucoma and primary angle closure glaucoma patients. Curr. Eye Res., 2014, 39(8), 823-829.

[22] Pan, H. Z., Zhang, H., Chang, D., et al.: The change of oxidative stress products in diabetes mellitus and diabetic retinopathy. Br. J. Ophthalmol., 2008, 92(4), 548-551.

[23] Cao, C., Prior, R. L.: Comparison of different analytical methods for assessing total antioxidant capacity of human serum. Clin. Chem., 1998, 44(6), 1309-1315.

[24] Krueger, R. R., Kuszak, J., Lubatschowski, H., et al.: First safety study of femtosecond laser photodisruption in animal lenses: tissue morphology and cataractogenesis. J. Cataract Refract. Surg., 2005, 31(12), 2386-2394.

[25] Soong, H. K., Malta, J. B.: Femtosecond lasers in ophthalmology. Am. J. Ophthalmol., 2009, 147(2), 189-197.e2.

[26] Soong, H. K., de Melo Franco, R.: Anterior chamber gas bubbles during femtosecond laser flap creation in LASIK: Video evidence of entry via trabecular meshwork. J. Cataract Refract. Surg., 2012, 38(12), 2184-2185.

[27] Krarup, T., Holm, L. M., la Cour, M., et al.: Endothelial cell loss and refractive predictability in femtosecond laser-assisted cataract surgery compared with conventional cataract surgery. Acta Ophthalmol., 2014, 92(7), 617-622.

[28] Mayer, W. J., Klaproth, O. K., Hengerer, F. H., et al.: Impact of crystalline lens opacification on effective phacoemulsification time in femtosecond laser-assisted cataract surgery. Am. J. Ophthalmol., 2014, 157(2), 426-432.el.

[29] Abell, R. G., Kerr, N. M., Howie, A. R., et al.: Effect of femtosecond laser-assisted cataract surgery on the corneal endothelium. J. Cataract Refract. Surg., 2014, 40(11), 1777-1783.

(Tóth Gábor dr., Budapest, Üllői út 26., 1085 e-mail: gabortothgabor@gmail.com) 